\title{
Pengaruh Modal Intelektual dan Pengungkapannya Terhadap Nilai Perusahaan: Efek Intervening Kinerja Perusahaan
}

\author{
RAHMA NURUL AIDA* \& EVI RAHMAWATI \\ Program Studi Akuntansi Universitas Muhammadiyah Yogyakarta, Jl. Lingkar Selatan, Tamantirto, Kasihan, Bantul, D.I. Yogyakarta, 55183, Telp \\ +274387656 , Indonesia. \\ *Corresponding Author, E_mail address: erahmawati77@gmail.com
}

\begin{abstract}
The aim of the research is to analyze and to get the empirical prove on the intellectual capital influence which is measured with VAIC and intellectual capital disclosure using Singh and Zahn index (2008) to the company value (EPS) with the company performance (ROE) as intervening variable. The sample of this research is the registered company of Indonesian Stock Market (2011-2013). The first and the second hypotheses were rejected. These may be caused of there was no basic standard to measure the intellectual capital value in Indonesia. The third hypothesis is accepted. The result of the research show that intellectual capital has positive effects to the company values indirectly through company performance as intervening variable. The fourth hypothesis successfully approved that intellectual capital disclosure has positive impact to the company performance. The fifth hypothesis was rejected. It may be caused by the intellectual capital which has not reflected the company value as it is non-salaried. The last hypothesis successfully proved that intellectual capital disclosure affects the company value through the company performance as intervening variable.

Keywords: Intellectual Capital; Intellectual Capital Disclosure;Company's Values; Company's Performance.
\end{abstract}

\begin{abstract}
ABSTRAK
Tujuan dari penelitian ini adalah untuk menganalisis dan untuk mendapatkan bukti empiris dari pengaruh modal intelektual yang diukur dengan VAIC dan pengungkapan modal intelektual menggunakan Singh dan Zahn indeks (2008) terhadap nilai perusahaan (EPS) dengan kinerja perusahaan (ROE) sebagai variabel intervening. Sampel dari penelitian ini adalah perusahaan yang terdaftar dari Bursa Efek Indonesia (2011-2013). Hipotesis pertama dan kedua. Hal ini mungkin disebabkan dari tidak ada standar dasar untuk mengukur nilai modal intelektual di Indonesia. Hipotesis ketiga diterima. Hasil penelitian menunjukkan bahwa modal intelektual memiliki efek positif terhadap nilai-nilai perusahaan secara tidak langsung melalui kinerja perusahaan sebagai variabel intervening. Hipotesis keempat diterima yang artinya pengungkapan modal intelektual berpengaruh positif terhadap kinerja perusahaan. Hipotesis kelima ditolak, hal ini mungkin disebabkan oleh modal intelektual yang belum mencerminkan nilai perusahaan. Hipotesis terakhir berhasil menemukan bukti bahwa pengungkapan modal intelektual mempengaruhi nilai perusahaan melalui kinerja perusahaan sebagai variabel intervening.

Kata Kunci:Modal Intelektual; Pengungkapan Modal Intelektual; Nilai Perusahaan;Kinerja Perusahaan.
\end{abstract}

\section{PENDAHULUAN}

Seiring dengan pengaruh globalisasi, ekonomi mengalami perkembangan pesat yang ditandai dengan adanya perkembangan di bidang inovasi, teknologi, dan juga persaingan dalam bisnis yang semakin ketat. Hal ini menimbulkan motivasi perusahaan-perusa-haan untuk mengubah metode bisnisnya. Perusahaan yang dulu mengan-dalkan tenaga kerja (labor based business) kini mulai beralih

ke dalam bidang pengetahuan (knowledge based business, dan menjadikan perusa-haannya sebagai peru-sahaan yang berbasis ilmu pengetahuan (Sawarjuwono, 2003). Hal tersebut membuat para pelaku bisnis gencar dalam menekankan aset tak berwujudnya, dalam hal ini adalah ilmu pengetahuan dan kemampuan untuk meningkatkan nilai perusahaan, sehingga 
perusahaan mampu untuk bersaing dengan para kompetitornya dan tidak hanya bersaing menggunakan kepemilikan aset berwujud saja. Industri yang sebelumnya menggunakan aset berjuwud sebagai tumpuan, kini mulai memperhatikan betapa penting dan berpo-tensinya aset tak berwujud dalam meningkatkan kinerja serta nilai perusahaannya (Fajarini dan Firmansyah, 2012).

Pulic (1998) menyatakan modal intelektual sebagai nilai tambah, value added intellectual coefficient (VAIC), memiliki tiga komponen dari sumber daya perusahaan, yaitu physical capita,l value added capital employed (VACA), human capital, value added human capital (VAHU), dan structural capital, structural capital value added (STVA). Sunarsih dan Mendra (2012) mengatakan bahwa semakin besar nilai modal intelektual (VAIC) maka penggunaan modal perusahaan akan semakin efisien, sehingga akan meningkatkan value added bagi perusahaan. Physical capital merupakan bagian dari modal intelektual yang menjadi sumber daya penentu kinerja perusahaan. Lalu, jika modal intelektual dianggap sebagai sumber daya yang terukur untuk peningkatan competitive advantages, maka modal intelektual akan memberikan kontribusi terhadap kinerja perusahaan (Abdolmohammadi, 2005). Modal intelektual diyakini dapat berperan penting dalam peningkatan nilai perusahaan dan kinerja keuangan.

Perusahaan yang mampu memanfaatkan modal intelektualnya secara efisien, maka nilai pasarnya akan meningkat (Sunarsih dan Mendra, 2012). Namun, pengungkapan ataupun penyampaian terkait modal intelektual oleh perusahaanperusahaan di Indonesia dinilai masih sangat minim. Hal itu berdampak negatif bagi perusahaanperusahaan yang kaya modal intelektual yang sedang mencari tambahan dana dari para pemilik modal ataupun stakeholder. Untuk menutup keterbatasan laporan akuntansi keuangan tradisional, Wallman (1995) menyarankan untuk melaporkan modal intelektual secara suka rela dalam laporan tahunan perusahaan untuk memenuhi kebutuhan informasi para stakeholders. Model pelaporan tersebut kemudian dikenal sebagai pengungkapan modal intelektual (Purnomosidhi, 2006).

Di Indonesia sendiri penelitian tentang modal intelektual telah banyak dilakukan, diantaranya Astuti dan Sabeni (2005), Ulum et al. (2008), Sianipar (2009) dan Solikhah et al. (2010) yang menemukan bahwa modal intelektual berpengaruh positif pada kinerja keuangan, sedangkan penelitian Kuryanto dan Muchamad (2008) serta Yuniasih et al. (2010) tidak berhasil membuktikan bahwa modal intelektual berpengaruh positif pada nilai pasar perusahaan (Sunarsih dan Mendra, 2012). Sedangkan pada hasil penelitian Sunarsih dan Mendra (2012) menunjukkan bahwa modal intelektual berpengaruh positif pada kinerja keuangan. Temuan penelitian ini meng-indikasikan bahwa semakin efisien perusahaan mengelola sumber daya intelektual (physical capital, human capital dan structural capital) yang dimiliki perusahaan akan memberikan hasil yang meningkat yang ditunjukkan dari peningkatan kinerja keuangan perusahaan.

Peneliti menduga hasil penelitian yang tidak konsisten tersebut disebabkan adanya variabel lain yang memediasi hubungan modal intelektual dengan nilai perusahaan yaitu kinerja keuangan. Perusahaan yang mampu mengelola sumber daya intelektual yang dimilikinya dengan efektif dan efisien, maka kinerja keuangannya akan meningkat. Kinerja keuangan yang meningkat akan direspon positif pasar sehingga nilai perusahaan akan meningkat. Berdasarkan argumentasi di atas, maka penelitian ini akan menguji secara empiris apakah kinerja perusahaan tersebut benar-benar menjadi 
variabel yang berperan sebagai variabel intervening.

Hasil penelitian ini menemukan modal intelektual dan pengungkapan modal intelektual memiliki pengaruh baik secara langsung maupun tidak langung dengan melibatkan kinerja perusahaan sebagai variabel intervening. Hasil analisis dan temuan penelitian dijelaskan secara detil di dalam paper. Hasil penelitian ini diharapkan dapat memberikan kontribusi terkait perkembangan literatur modal intelektual.

\section{TINJAUAN LITERATUR DAN PERUMUSAN HIPOTESIS}

\section{TEORI BERBASIS SUMBERDAYA}

Pendekatan berbasis sumber daya (resource-based view of the firm/RBV) adalah suatu teori yang dikembangkan untuk menganalisis keunggulan bersaing suatu perusahaan yang menonjolkan penge-tahuan (knowledge/learning economy) atau pereko-nomian yang mengandalkan aset-aset tak berwujud (intangible assets). Wernerfelt dalam Widarjo (2011) menjelaskan bahwa menurut pandangan Resource-Based Theory perusahaan akan semakin unggul dalam persaingan usaha dan mendapatkan kinerja keuangan yang baik dengan cara memiliki, menguasai, dan memanfaatkan asetaset strategis yang penting (aset berwujud dan tidak berwujud). Belkaoui (2003) menyatakan strategi yang berpotensi untuk mening-katkan kinerja perusahaan adalah dengan menyatukan aset berwujud dan aset tidak berwujud.

\section{TEORI PARA PEMANGKU KEPENTINGAN}

Berdasarkan teori stakeholder, mana-jemen organisasi melaksanakan kegiatan yang bermanfaat bagi stakeholder dan melaporkan kembali aktivitasaktivitas tersebut pada stakeholder (Deegan, 2004). Teori ini menyatakan bahwa seluruh stakeholder memiliki hak untuk disediakan informasi tentang bagaimana aktivitas organisasi mempengaruhi stakeholder, bahkan ketika stakeholder memilih untuk tidak menggunakan informasi tersebut dan ketika stakeholder tidak dapat secara langsung melaksanakan peran dalam kelangsungan hidup organisasi. Teori ini menyatakan bahwa organisasi akan memilih secara sukarela mengungkapkan informasi tentang kinerja lingkungan, sosial dan intelektual organisasi, melebihi dan di atas permintaan wajibnya, untuk memenuhi harapan yag diinginken stakeholder (Deegan, 2004; Sirojodin dan Nazaruddin, 2014)

\section{TEORI LEGITIMASI}

Suatu perusahaan akan secara sukarela melaporkan aktifitasnya jika manajemen menganggap bahwa hal ini adalah yang diharapkan komunitas (Deegan, 2004; Sirojodin dan Nazaruddin, 2014). Perusahaan akan lebih cenderung untuk melaporkan modal intelektual perusahaan jika perusahaan memiliki kebutuhan khusus untuk melakukannya. Hal ini mungkin terjadi ketika perusahaan menemukan bahwa perusahaan tersebut tidak mampu melegitimasi statusnya berdasarkan tangible assets yang umumnya dikenal sebagai simbol kesuksesan perusahaan (Ulum, 2007). Gutrie et al., (2004) mengemukakan bahwa disclosure dapat digunakan perusahaan untuk menunjukkan perhatian manajemen terhadap nilainilai kema-syarakatan (societal values), atau mengalihkan perhatian masyarakat terhadap dampak negatif yang timbul sebagai akibat kegiatan operasi perusahaan. Jadi, pengungkapan atau pemberian informasi mengenai Intellectual capital dalam laporan keuangan dapat digunakan untuk menunjukkan perhatian manajemen terhadap nilainilai masyarakat yang selanjutnya akan direspon oleh masyarakat dengan harga saham dari perusahaan yang telah mengungkapkan informasi tersebut. 


\section{TEORI SINYAL}

Teori sinyal menyatakan bahwa terdapat informasi yang diperoleh dan bermanfaat pada suatu pengungkapan yang dapat menjadi sinyal bagi investor dan pihak potensial lainnya dalam mengambil keputusan ekonomi. Suatu pengungkapan dikatakan mengandung informasi apabila dapat menimbulkan reaksi pasar, yaitu dapat berupa perubahan harga saham atau return saham. Apabila pengungkapan tersebut memberikan dampak positif berupa kenaikan harga saham, maka pengungkapan tersebut merupakan sinyal positif. Namun jika pengungkapan tersebut memberikan dampak negatif, maka pengungkapan tersebut merupakan sinyal negatif.

Berdasarkan teori ini maka suatu pengungkapan laporan tahunan perusahaan merupakan informasi yang penting dan dapat mempengaruhi investor dalam proses pengambilan keputusan, Octama (2011) menyatakan bahwa pengungkapan sukarela mengenai modal intelektual memungkinkan investor dan stakeholder lainnya untuk lebih baik dalam menilai kemampuan perusahaan di masa depan, melakukan penilaian yang tepat terhadap perusahaan, dan mengurangi persepsi risiko perusahaan. Perusahaan mengung-kapkan modal intelektual pada laporan keuangan dalam rangka memenuhi kebutuhan informasi investor, serta meningkatkan nilai perusahaan. Sinyal positif dari organisasi diharapkan akan mendapatkan respon positif dari pasar, hal tersebut dapat memberikan keuntungan bagi perusahaan serta memberikan nilai yang lebih tinggi bagi perusahaan. Menurut Oliviera (2008) seorang manajer memiliki motivasi untuk mengungkapkan private information secara sukarela karena perusahaan berharap informasi tersebut dapat diinterpretasikan sebagai sinyal positif mengenai kinerja perusahaan.

Pengungkapan sukarela modal intelektual memungkinkan bagi investor dan stakeholder lainnya untuk lebih baik dalam menilai kemampuan perusahaan di masa depan, melakukan penilaian yang tepat terhadap perusahaan, dan mengurangi persepsi risiko (Williams, 2001). Dengan mengungkapkan modal intelektual, perusahaan dapat lebih memberikan informasi mengenai kemampuan perusahaan dan keahlian perusahaan di bidangnya agar dapat menaikkan nilai perusahaan.

\section{MODAL INTELEKTUAL DAN}

\section{Pengungkapan Modal Intelektual}

Brooking (1996) menyatakan bahwa intellectual capital merupakan istilah yang diberikan kepada aset tidak berwujud yang merupakan gabungan dari pasar dan kekayaan intelektual yang berpusat pada manusia dan infrastruktur yang memungkinkan untuk menggerakkan dan mengembangkan perusahaan. Modal intelektual mencakup semua pengetahuan karyawan, organisasi dan kemampuan mereka untuk menciptakan nilai tambah dan menciptakan keunggulan kompetitif berkelanjutan. Modal intelektual telah diidentifikasi sebagai seperangkat tak berwujud (sumber daya, kemampuan dan kompetensi) yang menggerakkan kinerja organisasi dan penciptaan nilai (Bontis, 1998). Beberapa para ahli telah mengemukakan komponen apa saja yang terdapat dalam modal intelektual, salah satunya adalah Pulic (1998) yang mengem-bangkan metode VAIC ${ }^{\mathrm{TM}}$ untuk menyajikan informasi tentang value creation efficiency dari aset berwujud (tangible assets) dan aset tidak berwujud (intangible assets) yang dimiliki perusahaan.

Pengungkapan modal intelektual merupakan pemberian informasi mengenai modal intelektual yang dimiliki suatu perusahaan yang terdiri dari beberapa bagian, yaitu karyawan, pelanggan, teknologi informasi, proses, penelitian dan pengembangan, dan pernyataan strategi. Tujuan 
pengungkapan intellectual capital adalah untuk meningkatkan efektivitas internal dari operasi perusahaan (Bukh et al., 2005). Pengungkapan modal intelektual dalam suatu laporan keuangan sebagai suatu cara untuk mengungkapkan bahwa laporan tersebut menggambarkan aktifitas perusahaan yang kredibel, terpadu serta "true and fair" (Mouritsen et al., 2001).

\section{Kinerja Keuangan}

Kinerja keuangan perusahaan dapat diartikan sebagai pencapaian yang telah diwujudkan melalui pekerjaan yang telah dilakukan secara maksimal yang meliputi laporan laba rugi, neraca, dan laporan perubahan modal yang dapat digunakan sebagai alat ukur untuk mengetahui kinerja keuangan perusahaan pada periode tertentu (Sudibya dan Restuti, 2013). Kinerja perusahaan dalam penelitian ini diukur menggunakan $\mathrm{ROE}$ (Return on Equity). ROE mencerminkan kemampuan perusahaan dalam menghasilkan laba berdasarkan ekuitas yang dimilikinya. ROE yang lebih tinggi melebihi biaya modal yang digunakan, itu berarti perusahaan telah efisien dalam menggunakan modal sendiri, sehingga laba yang dihasilkan mengalami peningkatan dari tahuntahun sebelumnya.

\section{Nilai Perusahaan}

Nilai perusahaan adalah nilai jual suatu perusahaan dalam pasar modal. Nilai perusahaan merupakan bentuk memaksimalkan tujuan perusahaan melalui peningkatan kemakmuran para pemegang saham (Dewi dan Fidhayatin, 2012). Nilai perusahaan dalam penelitian ini diukur dengan earning per share (EPS) yang merupakan jumlah dari pendapatan per lembar saham perusahaan, dimana EPS dapat menunjukkan nilai suatu perusahaan dari seberapa besar pendapatan atas saham yang didapat perusahaan dari saham yang telah diinvestasikan (Sirojodin dan Nazaruddin, 2014).

\section{HUBUNGAN MODAL INTELEKTUAL DAN KINERJA PERUSAHAAN}

Berdasarkan teori berbasis sumber daya, sebuah perusahaan diartikan sebagai kumpulan dari aset maupun kemampuan berwujud dan tak berwujud (Firer dan Williams, 2003). Teori ini mendefinisikan perusahaan sebagai fungsi penggunaan yang efektif dan efisien dari aset berwujud maupun tak berwujud yang dimiliki oleh perusahaan atau intellectual ability. Hal ini sejalan dengan teori stakeholder yang menyatakan bahwa value added merupakan sebuah ukuran yang lebih akurat dalam mengukur kinerja sebuah perusahaan dibandingkan dengan laba akuntansi yang hanya merupakan ukuran return bagi pemegang saham (Pangestu dan Wijaya, 2014).

Pulic (1998) menyatakan bahwa pengukuran efisiensi modal intelektual VAIC ${ }^{\text {TM }}$ dapat membantu manajer untuk meningkatkan potensi perusahaannya ber-dasarkan kinerja bisnis saat ini. Disamping itu, hasil penelitian juga dinyatakan bahwa efisiensi modal intelektual memiliki nilai prediksi terhadap kinerja keuangan perusahaan (Chen et al., 2005, Tan et al., 2007, dan Sunarsih dan Mendra, 2012). Berdasarkan teori dan temuan hasil penelitian terdahulu, maka hipotesis yang diajukan dalam penelitian ini adalah:

H1: Modal intelektual berpengaruh positif terhadap kinerja keuangan perusa-haan.

\section{HUBUNGAN MODAL INTELEKTUAL, KINERJA PERUSAHAAN DAN NILAI PERUSAHAAN}

Menurut Brooking (1996) menyatakan bahwa intellectual capital merupakan istilah yang diberikan kepada aset tidak berwujud yang merupakan gabungan dari pasar dan kekayaan intelektual, yang berpusat pada manusia dan infrastruktur yang me- 
mungkinkan untuk menggerakkan dan mengembangkan perusahaan. Roos et al., (1997) dalam menyatakan bahwa intellectual capital adalah semua proses dan aset yang tidak biasanya dicantumkan pada neraca dan seluruh aset tidak berwujud (merek dagang, paten dan brands) yang dianggap sebagai metode akuntansi modern. Sedangkan Bontis (1998) mengakui bahwa modal intelektual sulit untuk dipahami, namun setelah ditemukan dan dikaji ulang, maka dapat memberikan sebuah organisasi basis sumber daya baru untuk bersaing dan menang (lihat: Ulum, 2008).

Definisi lain dari intellectual capital adalah sebagai jumlah dari apa yang dihasilkan oleh tiga komponen utama organisasi (human capital, structural capital, costumer capital) yang berkaitan dengan pengetahuan dan teknologi yang dapat memberikan nilai lebih bagi perusahaan berupa keunggulan bersaing organisasi. Oleh karenanya, dapat disimpulkan bahwa modal intelektual merupakan sumberdaya perusahaan yang berbasis penge-tahuan dan berupa aset tidak berwujud sehingga dapat dijadikan nilai tambah bagi perusahaan dan mampu digunakan perusahaan untuk menciptakan inovasi dan persaingan bisnis yang kompetitif (Sawarjuwono dan Kadir, 2003). Artinya semakin tinggi modal intelektual suatu perusahaan akan membuat nilai perusahaan tersebut semakin tinggi. Hal tersebut diperkuat dengan adanya penelitian terdahulu, Ulum (2007), Pramelasari (2010), Wijayanti (2013) yang menyatakan bahwa modal intelektual dapat meningkatkan nilai perusahaan. Modal intelektual diyakini dapat berperan penting dalam peningkatan nilai perusahaaan maupun kinerja keuangan.

Penelitian dengan tema nilai perusahaan telah banyak dilakukan. Termasuk Modigliani dan Miller (1958) dan Ulupui (2007) bahwa kinerja berpengaruh positif signifikan terhadap return saham satu periode kedepan dengan kata lain kinerja berpengaruh positif terhadap nilai perusahaan. Jadi, modal intelektual dapat meningkatkan kinerja perusahaan yang nantinya akan mempengaruhi nilai perusahaan. Berdasarkan teori dan temuan hasil penelitian terdahulu, maka hipotesis yang diajukan dalam penelitian ini adalah:

H2: Modal intelektual berpengaruh positif langsung terhadap nilai perusahaan.

H3: Modal intelektual berpengaruh positif tidak langsung terhadap nilai perusahaan melalui kinerja keua-ngan sebagai variabel intervening.

\section{HUBUNGAN PENUNGKAPAN MODAL INTELEKTUAL DAN KINERJA PERUSAHAAN}

Legitimacy theory mendorong perusahaan untuk melakukan pengungkapan sukarela sebagai salah satu bentuk pertanggungjawaban terhadap kontrak sosial yang dimiliki antara perusahaan dengan komunitas disekitarnya. Perusahaan cenderung melakukan pengung-kapan informasi melalui disclosure ketika muncul kebutuhan khusus untuk meningkatkan legitimasinya. Kebutuhan ini muncul ketika modal fisik yang dimiliki perusahaan, yang biasanya merupakan simbol kesuksesan pada ekonomi tradisional, ternyata kurang kuat dalam memberikan status legitimasi bagi perusahaan (Guthrie et al., 2004; Pangestu dan Wijaya, 2014). Status legitimasi perusahaan yang kuat berarti juga kepercayaan masyarakat bahwa perusahaan beroperasi sesuai dengan apa yang diharapkan oleh stakeholder, yaitu operasi yang meningkatkan kinerja perusahaan.

Beberapa penelitian terkait pengaruh tingkat pengungkapan modal intelektual terhadap kinerja perusahaan dilakukan oleh Abdolmohammadi (2005), Dumay dan Tull (2007) dan Pangestu dan Wijaya (2014). Dari penelitian yang mereka lakukan, ditemukan pengungkapan modal intelektual berpengaruh terhadap kinerja 
perusahaan Jadi, dengan mengungkapkan modal atas intelektualnya perusahaan dapat meningkatkan kinerja perusahaannya. Berdas-arkan teori dan temuan hasil penelitian terdahulu, maka hipotesis yang diajukan dalam penelitian ini adalah:

$\mathrm{H}_{4}$ : Pengungkapan Modal intelektual berpengaruh positif terhadap kinerja keuangan perusahaan.

\section{HUBUNGAN PENGUNGKAPAN MODAL INTELEKTUAL, KINERJA PERUSAHAAN DAN NILAI PERUSAHAAN.}

Teori sinyal menjelaskan bagaimana seharusnya sinyal-sinyal keberhasilan atau kegagalan manajemen disampaikan kepada pemilik. Perusahaan melakukan pengung-kapan terhadap modal intelektual dengan harapan dapat mengirimkan sinyal good news kepada pihak eksternal perusahaan bahwa perusahaan pada masa sekarang sedang berinvestasi dalam bentuk modal intelektual yang diharapkan akan memberikan keun-tungan ekonomi untuk perusahaan di masa yang akan datang sehingga pada akhirnya meningkatkan nilai dan citra perusahaan. Dengan nilai dan citra perusahaan yang bagus dimata pihak eksternal, maka akan mendorong pihak eksternal untuk berinvestasi ke dalam perusahaan. Oleh karena itu, perusahaan dengan profitabilitas yang masih rendah ataupun perusahaan-perusahaan yang baru berdiri, akan cenderung untuk mengungkapkan modal intelektual lebih banyak dalam laporan tahunan perusahaannya. Hal ini dilakukan untuk memberikan sinyal kepada pihak eksternal perusahaan bahwa perusahaan sedang berinvestasi dalam bentuk modal intelektual yang akan memberikan keuntungan di masa yang akan datang bagi perusahaan (Marisanti 2012).

Berdasarkan pendekatan Resource-Based Theory dapat disimpulkan bahwa sumber daya yang dimiliki perusahaan berpengaruh terhadap kinerja perusahaan yang pada akhirnya akan meningkatkan nilai perusahaan. Salah satu sumber daya yang dimiliki perusahaan dari aset tidak berwujud yang diungkapkan adalah modal intelektual. Jadi, pengungkapan modal intelektual sebagai sebuah sumber daya yang dimiliki oleh perusahaan berpengaruh terhadap kinerja perusahaan yang pada akhirnya akan meningkatkan nilai perusahaan, yang salah satunya dapat dilihat dari harga saham perusahaan (Wijayanti, 2013). Berdasarkan teori dan temuan hasil penelitian terdahulu, maka hipotesis yang diajukan dalam penelitian ini adalah:

$H_{5}$ : Pengungkapan Modal intelektual berpengaruh positif langsung terhadap nilai perusahaan.

$\mathrm{H}_{6}$ : Pengungkapan Modal intelektual berpengaruh positif tidak langsung terhadap nilai perusahaan melalui kinerja keuangan sebagai variabel intervening.

\section{METODE PENELITIAN}

\section{POPULASI DAN SAMPEL}

Populasi dalam penelitian ini adalah perusahaan yang terdaftar di Bursa Efek Indonesia. Periode penelitian mencakup data pada tahun 2010-2013, hal ini dimaksudkan untuk memperbaru objek penelitian. Sampel pada penelitian ini adalah perusahaan yang bergerak pada bidang manufaktur karena memliki cakupan lebih yang luas.

\section{TEKNIK PENGUMPULAN DATA}

Data dikumpulkan menggunakan penelusuran data sekunder melalui metode dokumentasi. Dokumentasi dilakukan dengan mengumpulkan data dokumenter seperti annual report perusahaan yang menjadi sampel penelitian.

\section{DEFINISI OPERASIONAL VARIABEL PENELITIAN Variabel Independen \\ Variabel modal intelektual yang dimaksud dalam penelitian ini adalah kinerja modal intelektual yang}


merupakan penciptaan nilai yang diperoleh atas pengelolaan modal intelektual. Pengukuran kinerja modal intelektual berdasarkan model yang dikembangkan oleh Pulic (1998), dimana kinerja modal intelektual diukur berdasarkan value added yang diciptakan oleh physical capital (VACE), human capital (VAHU), dan structural capital (STVA).

Kombinasi dari ketiga value added tersebut disimbolkan dengan VAIC ${ }^{\mathrm{TM}}$. Formulasi perhitungan VAIC $^{\mathrm{TM}}$ adalah sebagai berikut:

\section{Value Added (VA)}

VA adalah indikator paling obyektif untuk menilai keberhasilan bisnis dan menunjukkan kemampuan perusahaan dalam menciptakan nilai (value creation).

$$
\begin{aligned}
& \text { VA = OUT - IN } \\
& \text { Output (OUT): } \text { Total penjualan dan pendapatan lain. } \\
& \begin{array}{lll}
\text { Input (IN): } & \text { Beban dan biaya - biaya (selain beban karyawan) } \\
\text { VA: } & \text { selisih antara OUT dan IN }
\end{array}
\end{aligned}
$$

\section{Value Added of Capital Employed (VACA)}

$$
\text { VACA adalah indikator untuk VA yang }
$$

diciptakan oleh satu unit dari physical capital. VACA merupakan rasio dari VA terhadap CE (capital employed). Rasio ini menunjukkan kontribusi yang dibuat oleh setiap unit dari CE terhadap value added organisasi.

$$
\begin{array}{ll}
\text { VACA = VA/CE } \\
\text { VACA : } & \text { rasio dari VA terhadap CE. } \\
\text { CE : } & \text { dana yang tersedia (ekuitas + laba bersih) } \\
\text { Value Added } & \text { menunjukan berapa banyak VA dapat } \\
\text { Human } & \text { dihasilkan dengan dana yang dikeluarkan } \\
\text { Capital } & \text { untuk tenaga kerja. } \\
\text { (VAHU) } &
\end{array}
$$

\section{Structural Capital Value Added (STVA)}

STVA menunjukkan kontribusi structural capital (SC) dalam penciptaan nilai. STVA merupakan rasio dari SC terhadap VA. Rasio ini mengukur jumlah SC yang dibutuhkan untuk menghasilkan 1 rupiah dari VA dan merupakan indikasi bagaimana keberhasilan SC dalam penciptaan nilai.

$$
\begin{aligned}
& \text { SC }=\text { VA }- \text { HC } \\
& \text { STVA = SC/VA } \\
& \text { VA: selisih antara OUT dan IN } \\
& \text { HC: beban karyawan } \\
& \text { SC: selisih antara VA dan HC }
\end{aligned}
$$

\section{Value Added Intellectual Coefficient (VAIC)}

Model VAIC menyajikan value added intellectual capital coefficient yang merupakan gabungan dari ketiga koefisien yaitu Physical Capital, Human Capital dan Structural Capital.

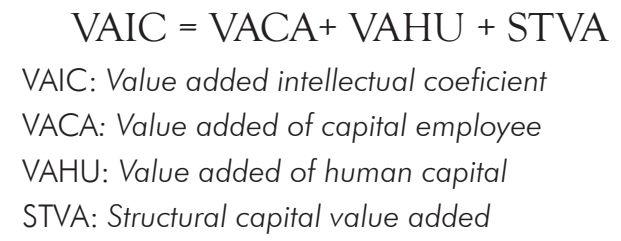

Indeks pengungkapan modal intelektual dalam penelitian ini menggunakan indeks pengungkapan yang dikemukakan oleh Singh dan Zahn (2008) yang merupakan pengembangan dari indeks Bukh et al. (2005). Pengungkapan modal intelektual diukur melalui enam dimensi yang meliputi karyawan, konsumen, teknologi informasi, proses, penelitian dan pengembangan, serta pernyataan strategi. Prosentase dari indeks pengungkapan sebagai total dihitung menurut rumusan yang berikut:

Score $=(\Sigma \mathrm{di} / \mathrm{M}) \times 100 \%$
Score: Variabel dependen indeks pengungkapan modal
intelektual (ICD Index)
di: $\quad 1$ jika item modal intelektual dilaporkan dalam

M: $\quad$ laporan tahunan dan 0 jika tidak dilaporkan
total jumlah item yang diukur (81 item)

\section{Variabel Dependen}

Variabel depeden dalam penelitian ini adalah nilai perusahaan yang diukur menggunkan Earnings per share (EPS). EPS memberikan ukuran profitabilitas yang memasukkan keputusan operasi, investasi dan pembiayaan (Stikney dan Weil dalam 

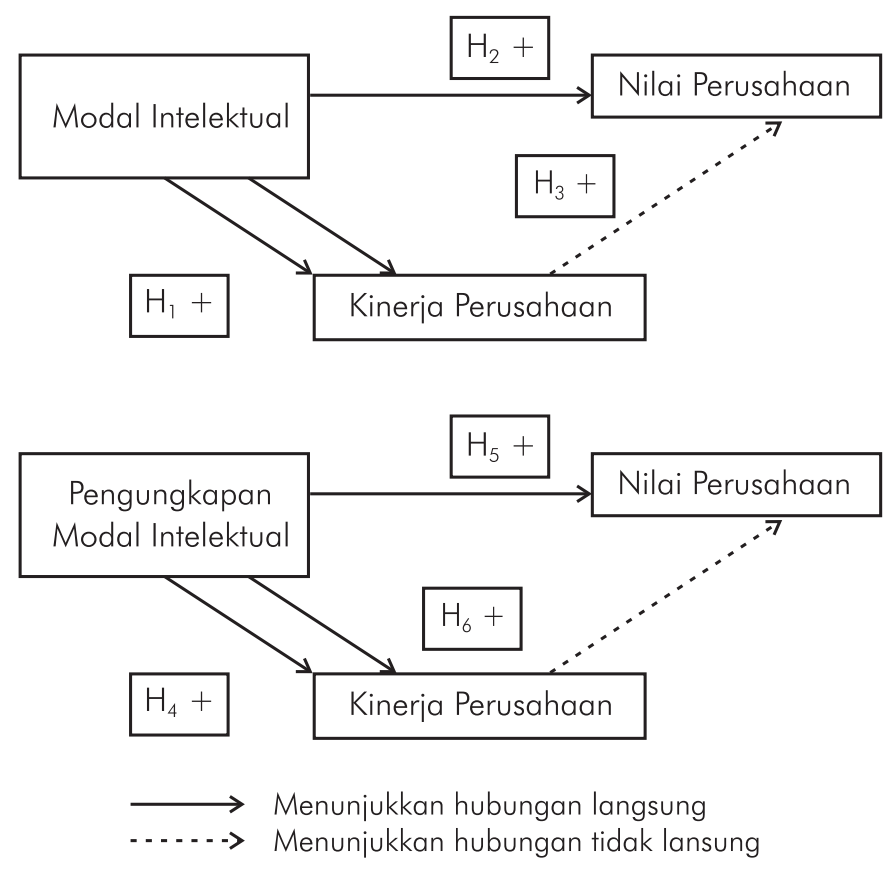

GAMBAR 1. MODEL PENELITIAN

Hong, 2007). Nilai EPS di dapat dengan menggunakan rumus:

EPS $=$ Jumlah dana pemegang saham

Laba pemegang saham

\section{Variabel Intervening}

Variabel intervening dalam penelitian ini adalah kinerja keuangan. Pengukuran kinerja keuangan dalam penelitian ini menggunakan Return on Equity (ROE). ROE mengukur seberapa banyak keuntungan sebuah perusahaan dapat menghasilkan setiap rupiah dari modal pemegang saham. Rasio ini mengindikasi kekuatan laba dari investasi nilai buku pemegang saham dan digunakan ketika membandingkan dua atau lebih dua perusahaan dalam sebuah industri secara kontinu. Jadi formula untuk memperoleh ROE:

$$
\mathrm{ROE}=\frac{\text { Laba bersih }}{\text { total ekuitas }} \times 100
$$

\section{Model Empiris}

Metode analisis menggunakan metode regresi berganda dengan uji asumsi klasik yang dipersyaratkan dalam model, serta menggunakan analisis jalur (path analysis) yang merupakan perluasan dari analisis regresi berganda untuk melihat apakah terdapat hubungan kausalitas antar variabel. Dalam analisis penenelitian ini terdapat satu variabel yang memiliki peran ganda yaitu sebagai variabel independen dalan suatu hubungan dan juga sebagai variabel pada hubungan yang lain. Rumus regresi untuk menguji hipotesis yang menjelaskan hubungan modal intelektual dengan nilai perusahaan adalah sebagai berikut:

$$
\begin{gathered}
\mathrm{ROE}=\alpha+\beta_{1} \mathrm{ICDi}+e_{1} \\
\mathrm{EPS}=\alpha+\beta_{1} \mathrm{ICDi}+\beta_{2} \mathrm{ROE}+e_{2}
\end{gathered}
$$

Keterangan:

ROE : Kinerja keuangan (return of equity)

EPS : Nilai perusahaan (earning per share)

ICD : Pengungkapan modal intelektual (intellectual capital disclosure index) $\beta_{1}, \beta_{2}$ : Koefisien jalur ROE dengan ICD

e : Error 
menjelaskan hubungan pengungkapan modal intelektual dengan nilai perusahaan.

$$
\begin{gathered}
\mathrm{ROE}=\alpha+\beta_{1} \mathrm{VAIC}+e \\
\mathrm{EPS}=\alpha+\beta_{1} \mathrm{VAIC}+\beta_{2} \mathrm{ROE}+e
\end{gathered}
$$

Keterangan

ROE : Kinerja keuangan (return of equity)

VAIC: Modal intellectual (value added intellectual capital)

EPS : Nilai perusahaan (earning per share)

$\beta_{1}, \beta_{2}$ : Koefisien jalur ROE dengan VAIC

e : Error

\section{HASIL DAN PEMBAHASAN}

Jumlah pengamatan dalam penelitian ini adalah 158 sampel. Variabel modal intelektual (VAIC) memiliki nilai minimum -0.1744 , nilai maksimum 5,1696 dan rata-rata 3,3684 dengan standar deviasi 1,0497. Variabel pengungkapan modal intelektual (ICD) memiliki nilai minimum 1,7918 , nilai maksimum 3.8067 dan rata-rata 3.0178 dengan standar deviasi 0,3883. Variabel nilai perusahaan memiliki nilai minimum 0,4824 , nilai maksimum 12,3118 dan rata-rata 4,7830 dengan standar deviasi 2,0941. Variabel kinerja perusahaan memiliki nilai minimum 0,2390, nilai maksimum 4,9233 dan rata-rata 2,6306 dengan standar deviasi 0,8850.

Dari Tabel 2 dapat diketahui bahwa variabel modal intelektual (VAIC) memiliki koefisien negatif sebesar -0,128 dengan nilai sig. sebesar 0,058 $>0,05$, artinya VAIC tidak berpengaruh secara signifikan terhadap kinerja keuangan (ROE), sehingga hipotesis satu $\left(\mathrm{H}_{1}\right)$ dalam penelitian ini tidak diterima. Variabel modal intelektual (VAIC) memiliki koefisien dengan arah negatif sebesar 0,133 dengan nilai sig. sebesar 0,322>0,05, artinya VAIC tidak berpengaruh secara signifikan terhadap nilai perusahaan (EPS), sehingga hipotesis dua $\left(\mathrm{H}_{2}\right)$ dalam penelitian ini tidak diterima.

Hipotesis ketiga modal intelektual (VAIC) terhadap nilai perusahaan (EPS) dengan kinerja keuangan (ROE) sebagai variabel intervening. Dapat diketahui koefisien positif sebesar 1,308 dengan nilai sig. $0.000<0,05$. Artinya hasil analisis menunjukkan bahwa VAIC berpengaruh signifikan secara tidak langsung terhadap EPS melalui ROE sebagai variabel intervening. Hipotesis tiga $\left(\mathrm{H}_{3}\right)$ dalam penelitian ini diterima. Variabel pengungkapan modal intelektual (ICD) memiliki koefisien positif sebesar 0,844 dengan nilai sig. sebesar 0,000 $>0,05$, artinya ICD berpengaruh secara signifikan terhadap kinerja keuangan (ROE),sehingga hipotesis tiga $\left(\mathrm{H}_{3}\right)$ dalam penelitian ini diterima.

Variabel pengungkapan modal intelektual (ICD) memiliki koefisien dengan arah negatif sebesar 0,006 dengan nilai sig. sebesar 0,988>0,05, artinya ICD tidak berpengaruh secara signifikan terhadap nilai perusahaan (EPS), sehingga hipotesis lima $\left(\mathrm{H}_{5}\right)$ dalam penelitian ini ditolak. Hipotesis keenam pengungkapan modal intelektual (ICD) terhadap nilai perusahaan (EPS) dengan kinerja keuangan (ROE) sebagai variabel intervening. Dapat diketahui koefisien positif sebesar 1,333 dengan nilai sig. $0.000<0,05$. Artinya hasil analisis menunjukkan bahwa ICD berpengaruh signifikan secara tidak langsung terhadap EPS melalui ROE sebagai variabel intervening, sehingga hipotesis enam $\left(\mathrm{H}_{6}\right)$ dalam penelitian ini diterima.

TABEL 3. PERHITUNGAN PATHANALYS

\begin{tabular}{lllllll}
\hline \multirow{2}{*}{ Variabel } & VAIC & \multicolumn{5}{l}{ ROE } \\
\cline { 2 - 7 } & PL & PTL & PT & PL & PTL & PT \\
\hline ROE & $-0,151$ & - & $-0,151$ & - & - & - \\
EPS & $-0,067$ & 0,010 & $-0,057$ & 0,553 & - & 0,533 \\
\hline \multirow{2}{*}{ Variabel } & ICD & & & ROE & & \\
\cline { 2 - 7 } & PL & PTL & PT & PL & PTL & PT \\
\hline ROE & 0,370 & - & 0,370 & - & - & - \\
EPS & $-0,001$ & 0,000 & $-0,001$ & 0,563 & - & 0,563 \\
\hline
\end{tabular}

Pada Tabel 3 ditunjukkan besarnya pengaruh langsung modal intelektual pada kinerja perusahaan adalah $-0,151$. Besarnya pengaruh langsung modal intelektual pada nilai perusahaan 
adalah $-0,067$. Besarnya pengaruh modal intelektual pada nilai perusahaan melalui kinerja sebagai variabel intervening yaitu $0,010(-0,151 \times-0,067)$ sehingga pengaruh totalnya menjadi $-0,057$. Pesarnya pengaruh langsung pengungkapan modal intelektual pada kinerja perusahaan adalah 0,370. Besarnya pengaruh langsung modal intelektual pada nilai perusahaan adalah -0,001. Besarnya pengaruh modal intelektual pada nilai perusahaan melalui kinerja sebagai variabel intervening yaitu $0,000(0,370 \times-0,001)$ sehingga pengaruh totalnya menjadi $-0,001$.

Besarnya kontribusi modal intelektual terhadap kinerja perusahaan yaitu $(-0,151)^{2}=0,0228$ atau 2,28\%. Kontribusi pengaruh langsung modal intelektual pada nilai perusahaan adalah $(-0,067)^{2}=$ $0,0043 \%$ atau $0,43 \%$. Kontribusi pengaruh kinerja perusahaan pada nilai perusahaan adalah $(0,553)^{2}=$ 0,3058 atau 30,58\%. Hal ini berarti kinerja perusahaan sebagai variabel intervening memeberikan kontribusi tambahan yang cukup besar yaitu 30,58\%, sehingga kontribusi pengaruh modal intelektual pada nilai perusahaan melalui kinerja sebagai variabel intervening adalah $(-0,151)^{2}+$ $(0,553)^{2}=0,3286$ atau 32,86\%.

Besarnya kontribusi pengungkapan modal intelektual terhadap kinerja perusahaan yaitu $(0,370)^{2}=0,1369$ atau $13,69 \%$. Kontribusi pengaruh langsung pengungkapan modal intelektual pada nilai perusahaan adalah $(0,001)^{2}=$ 0,000001\% atau 0,0001\%. Kontribusi pengaruh kinerja perusahaan pada nilai perusahaan adalah $(0,563)^{2}=0,3169$ atau 31,69\%. Hal ini berarti kinerja perusahaan sebagai variabel intervening memeberikan kontribusi tambahan yang cukup besar yaitu 31,69\%, sehingga kontribusi pengaruh modal intelektual pada nilai perusahaan melalui kinerja sebagai variabel intervening adalah $(0,370)^{2}$ $+(0,563)^{2}=0,4538$ atau $45,38 \%$.

\section{SIMPULAN}

Hasil penelitian menemukan bahwa modal intelektual tidak berpengaruh terhadap kinerja keuangan dan nilai perusahaan. Kemungkinan

TABEL 1. STATISTIK DESKRIPTIF

\begin{tabular}{llllll}
\hline & N & Minimum & Maximum & Mean & Std. Deviation \\
\hline Modal Intelektual & 158 & $-0,1744$ & 5,1696 & 3,3684 & 1,0497 \\
$\begin{array}{l}\text { Pengungkapan Modal } \\
\text { Intelektual }\end{array}$ & 158 & $1,79,18$ & 3,8067 & 3,0178 & 0,3883 \\
Nilai Perusahaan & 158 & 0,4824 & 12,3118 & 4,7830 & 2,0941 \\
Kinerja Perusahaan & 158 & 0,2390 & 4,9233 & 2,6306 & 0,8850 \\
\hline
\end{tabular}

TABEL 2. RINGKASAN UJI NILAI T

\begin{tabular}{lllll}
\hline Model & Hubungan & $\begin{array}{l}\boldsymbol{\beta} \\
\text { Unstandardized } \\
\text { Coefficients }\end{array}$ & $\begin{array}{l}\text { Beta } \\
\text { Standardized } \\
\text { Coefficients }\end{array}$ & Sig. \\
\hline 1 & VAIC $\rightarrow$ ROE & -.128 & -.151 & .058 \\
& VAIC $\rightarrow$ EPS & -.133 & -.067 & .322 \\
2 & ROE $\rightarrow$ EPS & 1.308 & .553 & .000 \\
3 & ICD $\rightarrow$ ROE & .844 & .370 & .000 \\
4 & ICD $\rightarrow$ EPS & -.006 & -.001 & .988 \\
& ROE $\rightarrow$ EPS & 1.333 & .563 & .000 \\
\hline
\end{tabular}


tidak adanya penambahan kinerja disebabkan oleh belum ada standar yang baku untuk mengukur modal intelektual di Indonesia. Pasar mungkin lebih menghargai faktor lain seperti laba dan faktor fundamental yang dicapai dibandingkan modal intelektual yang dimiliki perusahaan. Namun modal intelektual berpengaruh positif secara tidak langsung terhadap nilai perusahaan dengan kinerja keuangan sebagai variabel intervening. Hasil penelitian ini didukung oleh penelitian Sunarsih dan Mendra (2012) yang membuktikan bahwa kinerja keuangan sebagai variabel intervening mampu memediasi hubungan antara modal intelektual dengan nilai perusahaan.

Pengungkapan modal intelektual berpengaruh positif terhadap kinerja perusahaan. Hal ini menunjukkan bahwa pasar memberikan penilaian yang lebih tinggi pada perusahaan yang memiliki modal intelektual yang lebih tinggi dengan melihat kinerja keuangan. Hal ini akan menarik perhatian investor untuk memberikan nilai yang tinggi pada perusahaan. Hasil penelitian ini didukung oleh penelitian Sunarsih dan Mendra (2012) yang membuktikan bahwa kinerja keuangan sebagai variabel intervening mampu memediasi hubungan antara modal intelektual dengan nilai perusahaan.

Pengungkapan modal intelektual juga tidak berpengaruh terhadap nilai perusahaan.

Pengungkapan atas modal intelektual kemungkinan masih dinilai rendah oleh pasar yang cenderung menilai dari segi kekayaan secara finansial dibandingkan dengan segi kekayaan intelektual. Pengungkapan atas modal intelektual juga masih bersifat sukarela sehingga belum bisa merefleksikan nilai perusahaan. Pengung-kapan modal intelektual berpengaruh positif secara tidak langsung terhadap nilai perusahaan dengan kinerja perusahaan sebagai variabel intervening. Kinerja keuangan sebagai variabel intervening mampu memediasi hubungan antara pengungkapan modal intelektual dan nilai perusahaan. Dengan meningkatnya kinerja keuangan maka akan direspon positif pasar sehingga nilai perusahaan akan meningkat.

Beberapa keterbatasan yang ada pada penelitian ini yakni, pertama penelitian hanya menggunakan sampel yang terdiri dari perusahaan yang terdaftar di Bursa Efek Indonesia sepanjang tahun 2011 sampai 2013. Perusahaan yang mengalami delisting dalam periode tersebut tidak termasuk ke dalam sampel. Hal ini berpotensi menyebabkan terjadinya survivorship bias. Namun, peneliti telah melakukan pengujian dengan menggunakan nilai rata-rata masing-masing variabel selama periode pengamatan. Pengujian ini diharapkan memberikan hasil yang lebih valid dan meminimalkan kemungkinan bias tersebut. Kedua, pemilihan sampel dalam penelitian ini dilakukan dengan metode purposive sampling sehingga sampel yang diperoleh menjadi lebih sedikit. Penelitian selanjutnya diharapkan dapat mencakup perusahaan dari semua jenis industri sehingga hasil penelitian lebih dapat di generalisasi.

Berangkat dari keterbatasan penelitian tersebut, maka saran untuk penelitian selanjutnya adalah, pertama dapat mempertimbangkan untuk menggunakan metoda pengukuran langsung seperti balanced scorecard, real options model, atau skandia navigator (Stewart, 1997 dan Abdolmohammadi, 2005). Kedua, penelitian selanjutnya diharapkan dapat mencakup perusahaan dari semua jenis industri dan memperpanjang periode pengamatan sehingga hasil penelitian lebih dapat di generalisasi dan pengaruh modal intelektual pada nilai perusahaan lebih konsisten. Ketiga, penelitian selanjutnya dapat menguji kembali pengaruh modal intelektual pada nilai perusahaan dengan menggunakan model lain dan menambahkan variabel kontrol dan menggunakan pengukuran lain untuk mengukur nilai perusahaan, seperti price book value (PBV) atau market to book ratio (MBR). 


\section{DAFTAR PUSTAKA}

Abdolmuhammadi, M. J. 2005. Intellectual Disclosure and Market Capitalization. , 397-416.

Astuti, P.D. 2005. Hubungan Intellectual Capital dan Business Performance. Jurnal MAKSI, 5, 34-58.

Belkaoui, A. R. 2003. Intellectual Capital And Firm Performance Of US Multinational Firms: A Study Of The Resource-Based And Stakeholder Views. Journal of Intellectual Capital, 4 (2), 215-226.

Boedi, S. 2008. Pengungkapan Intellectual Capital dan Kapitalisasi Pasar (Studi Empiris pada Perusahaan Publik di Indonesia. Tesis Universitas Diponegoro.

Bontis, N. 1998. Intellectual capital: an exploratory study that develops measures and models. Management Decision, 36 (2), 63-76.

Bukh, P., 2002. The Relevance of Intellectual Capital Disclosure: A Paradox?. Accounting, Auditing \& Accountability Journal, 16, 49-56.

Chen, M.C., S.J. Cheng dan Y. Hwang. 2005. An Empirical Investigation of the Relationship between Intellectual Capital and firms' Market Value and Financial Performances. Journal of Intellectual Capital, 6 (2), 159-176

Deegan, C. 2004. Financial Accounting Theory. Sydney: McGraw-Hill Book Company.

Dewi, N. H. U. dan S. K. Fidhayatin. 2010. Analisis Nilai Perusahaan, Kinerja Perusahaan, dan Kesempatan Bertumbuh Perusahaan Terhadap Return Saham pada Perusahaan Manufaktur yang Lisitng di BEI. The Indonesian Accounting Review, 2 (2), 203-214

Dumay, J.C. dan J.A. Tull. 2007. Intellectual Capital Disclosure and Price-Sensitive Australian Stock Exchange Announcements. Journal of Intellec-tual Capital, 236-255.

Fajarini, I., dan R. Firmansyah. 2012. Pengaruh Intellectual Capital Terhadap Kinerja Keuangan Perusahaan (Studi Empiris Perusahaan LQ 45). Jurnal Dinamika Akuntansi, 4 (1), 1-12.

Firer, S. dan S.M. Williams. 2003. Intellectual Capital and Tradisional Measures of Corporate Performance. Journal of Intellectual Capital, 4 (3), 348-360.

Ghozali, I. 2011. Aplikasi Analisis Multivariate dengan Program IBM SPSS 19. Edisi 5. Semarang: Badan Penerbit Universitas Diponegoro.

Guthrie, J dan I. Abeyesekera. 2004. How is Intellectual Capital Being Reported in A Developing Nation?. University of Wollongong Research Online.

Ikatan Akuntan Indonesia. 2007. Pernyataan Standar Akuntansi Keuangan No. 19. Jakarta: Salemba Empat.

Kuryanto, B. dan M. Syafrudin. 2008. Pengaruh Modal Intelektual Terhadap Kinerja Perusahaan. Paper dipresentasikan pada Simposium Nasional Akuntansi XI, Pontianak.

Marisanti, E. K.. 2012. Analisis Hubungan Profitabilitas terhadap Pengungkapan Intellectual Capital. Diponegoro Journal of Accounting, 1 (2), 1-11.

Modigliani, F. dan M. H. Miller. 1958. The Cost of Capital, Corporation Finance and the Theory of Investment Author. The American Economic Review, 48 ( ), 261-297.

Mouritsen, J. 1998. Driving Growth: Economic Value Added versus Intellectual Capital. Management Accounting Research, 9, 461-482.

Octama, M. I. 2011. Analisis Faktor-Faktor Penentu Pengungkapan Modal Intelektual dan Pengaruhnya terhadap Harga Saham. Skripsi Universitas Diponegoro

Oliveira, L., L. L. Rodrigues dan R. Craig. 2008. Applying Voluntary
Disclosure Theories to Intangibles Reporting: Evidence from the Portuguese Stock Market

Pangestu A. D. dan R. E. Wijaya. 2014. Pengaruh Intellectual Capital Terhadap Market Value dan Kinerja Keuangan. Jurnal Akuntansi dan Investasi, 15 (2), 117-129.

Pulic, A. 1998. Measuring the Performance of Intel-lectual Potential in Knowledge Economy. Paper dipresentasikan di 2nd McMaster Word Congress on Measuring and Managing Intellectual Capital by the Austrian Team for Intellectual Potential.

Purnomosidhi, B. 2006. Praktik Pengung-kapan Modal Intelektual pada Perusahaan Publik di BEJ.

Roos, J., G. Roos, N. C. Dragonetti dan L. Edvinsson. 1997. Intellectual Capital: Navigating the New Business Landscape. London: Macmillan.

Santoso, S. 2010. Pengaruh Modal Intelektual dan Pengungkapannya Terhadap Kinerja Perusahaan. Jurnal Auntansi dan Keuangan, 14 (1), 16-31

Sawarjuwono, T. dan A. P. Kadir. 2003. Intellectual Capital: Perlakuan, Pengukuran dan Pelaporan (Sebuah Library Research). Jurnal Akuntansi dan Keuangan, 5 (1), 31-51.

Sianipar, M. 2009. The Impact of Intelectual Capital towards Financial Profitability and Investors' Capital Gain on Shares: An Empirical Investigation of Indonesian Banking and Insurance Sector for Year 2005-2007. Makalah Disampaikan dalam Simposium Nasional Akuntansi XII, Palembang

Singh, I. dan J-L. W. M. Zahn. 2008. Determinants of Intellectual Capital Disclosure in prospectuses of Initial public Offerings. Accounting and Business Research, 38 (5), 409-431.

Sirojodin, G. A. dan I. Nazaruddin. 2014. Pengaruh Modal Intelektual dan Pengungkapannya terhadap Nilai dan Kinerja Perusahaan. Jurnal Akuntansi dan Investasi, 15 (2), 101-118.

Solikhah, B., A. Rohman dan W. Meiranto. 2010. Implikasi Intellectual Capital terhadap Financial Performance, Growth dan Market Value Studi Empiris dengan Pendekatan Simplisitic Specification. Makalah Disampaikan dalam Simposium Nasional Akuntansi XIII, Purwokerto.

Sudibya, C. N . A dan M. D. Restuti. 2013. Pengaruh Modal Intelektual terhadap Nilai Perusahaan dengan Kinerja Keuangan sebagai Variabel Intervening. Seminar Nasional dan Call for Paper (Sancall 2014). Research Methods and Organizational Studies, 154-166.

Sunarsih, N. M dan N. P. Y. Mendra. 2012. Pengaruh Modal Intelektual Terhadap Nilai Perusahaan Dengan Kinerja Keuangan Sebagai Variabel Intervening Pada Perusahaan Yang Terdaftar Di Bursa Efek Indonesia. Paper diperesentasikan di Simposium Nasional Akuntansi XV, Banjarmasin.

Tan, H. P., D. Plowman dan P. Hancock. 2007. Intellectual Capital and Financial Retuns of Companies. Journal of Intellectual Capital, 8 (1), 76-95.

Ulum, I. 2008. Pengaruh Intellectual Capital terhadap Kinerja Keuangan Perusahaan Perbankan di Indonesia. Tesis Universitas Diponegoro

Ulupui, I. G. K. A. 2005. Analisis Pengaruh Rasio Likuiditas, Leverage, Aktivitas, dan Profitabilitass terhadap Return Saham (Studi pada Perusahaan Makanan dan Minuman dengan Kategori Industri Barang Konsumsi di BEJ. Skripsi, Universitas Udayana.

Watts, R. L. dan J. L. Zimmerman. 1986. Positive Accounting Theory. Englewood Cliffs. NJ: Prentice-Hall.

Widarjo, W. 2011. Pengaruh Modal Intelektual dan Pengungkapan Modal Intelektual pada Nilai Perusahaan. Paper dipresentasikan di 
Simposium Nasional Akuntansi XIV, Aceh.

Wijayanti, P. 2013. Pengaruh Intellectual Capital terhadap Harga Saham melalui Kinerja Keuangan pada Perusahaan Perbankan yang Terdaftar di Bursa Efek Indonesia (BEI).

Williams, M. 2001. Are intellectual capital performance and disclosure practice related? Journal of Intellectual Capital, 2 (3), 192-203.

Yuniasih, N., D. G. Wirama dan D. N. Badera. 2010. Eksplorasi Kinerja Pasar Perusahaan: Kajian Berdasarkan Modal Intelektual. Paper dipresen-tasikan di Simposium Nasional Akuntansi XIII,

Purwokerto. 